The Journal of Animal \& Plant Sciences, 31(1): 2021, Page: 131-142

ISSN (print): 1018-7081; ISSN (online): 2309-8694

\title{
METHIONINE-INDUCED CHANGES IN GROWTH, GLYCINEBETAINE, ASCORBIC ACID, TOTAL SOLUBLE PROTEINS AND ANTHOCYANIN CONTENTS OF TWO Zea mays L. VARIETIES UNDER SALT STRESS
}

\author{
S. Perveen* and S. A. Hussain \\ Department of Botany, Government College University, Faisalabad-38000, Pakistan \\ *Corresponding author's email: perveens1@yahoo.com
}

\begin{abstract}
A pot study was performed to evaluate the influence of methionine $\left(0,25\right.$ and $\left.50 \mathrm{mg} \mathrm{L}^{-1}\right)$ as foliar spray on maize (Zea mays L.) varieties named as DTC (hybrid) and Malika under salt $(90 \mathrm{mM} \mathrm{NaCl})$ stress. Seeds of both maize varieties were sown in plastic pots under completely randomized design. Two-week-old maize plants were subjected to two levels of salt stress i.e., 0 and $90 \mathrm{mM}(\mathrm{NaCl})$ in full strength Hoagland's nutrient solution. Foliar application of different methionine levels $\left(0,25\right.$ and $\left.50 \mathrm{mg} \mathrm{L}^{-1}\right)$ was applied to four-week-old maize plants. A three way analysis of variance (ANOVA) of data of 11-week-old plants of maize plants showed that salt stress considerably reduced the growth, chlorophyll, relative water content (\%), free amino acids and flavonoid contents, whereas improved membrane permeability (\%), total leaf area per plant, glycine betaine (GB), total soluble proteins, free proline, anthocyanin and ascorbic acid contents of both maize varieties. Maize var. Malka was greater in fresh weight of root, total chlorophyll and total soluble protein contents, while DTC (hybrid) excelled in anthocyanin, total soluble sugars and flavonoid contents. Methionine as foliar application significantly improved dry shoot weight, fresh root weight, GB, total soluble protein, ascorbic acid and anthocyanin contents of two maize varieties under salinity stress. Of the varying methionine levels, $50 \mathrm{mg} \mathrm{L}^{-1}$ proved better in decreasing the adverse influence of $\mathrm{NaCl}$ stress on both varieties [DTC (hybrid) and Malika] of maize.
\end{abstract}

Key words: proteins, salinity, oxidative stress, vitamins, ascorbic acid.

https://doi.org/10.36899/JAPS.2021.1.0201

Published online August 26, 2020

\section{INTRODUCTION}

Salinity stress is among the main abiotic strains that significantly decrease growth as well as yield of major food cultivations globally. Salinity stress disturbs metabolic processes by the formation of reactive oxygen species that damage membrane system of cytoplasmic organelles (Nazar et al., 2011). Plants tolerance towards salt stress greatly depends upon the capability of its cytoplasmic structure and its interaction with external environment. This capability can be improved and enhanced by the use of amino acids under salt stress (Wang et al., 2010). For example, exogenous applications of amino acids has been reported to reduce abiotic stresses in various crop species such as wheat (El-Said and Mahdy, 2016), maize (Alam et al., 2017), rice (Xiaochuang et al., 2017), barley (Genisel et al., 2015), potato (Awad et al., 2007), faba bean (Sadak et al., 2015), Arabidopsis thaliana (Dominguez-Solis et al., 2004) and canola (Lei et al., 2016) etc..

About $80 \%$ human food is derived from crops in which only cereals (wheat, rice and maize) contribute $50 \%$ of total food production throughout the world (Langridge and Fleury, 2011). However, major food crops are deficient in vital amino acids such as lysine plus tryptophan in cereals (Pfefferle et al., 2003), isoleucine, cysteine and methionine in potatos (Stiller et al., 2007), and threonin and methionine in soybeans (Muntz et al., 1998). Malnutrition in micronutrients (iron, zinc, vitamins) and macronutrients (amino acids methionine and lysine) can affect more than $40 \%$ of human population globally (Hesse et al., 2004). Human beings can synthesize only ten of the twenty amino acids, while the remaining ten are obtained from diet. However, some food crops like cereals are deficient in crucial amino acids e.g., tryptophan, threonine and lycine, while leguminous crops did not contain adequate supply of sulphure-containing amino acids like cysteine and methionine. In developing countries, people depend upon plant-derived food and $90 \%$ of energy intake can be derived from a single plant species that could be low in methionine contents leading to protein energy malnutrition (PEM) in humans. Plant derived food that is deficient in methionine can decrease growth of animals (Xu et al., 1998). In order to increase nutritional quality contents of essential amino acids like tryptophan, methionine, and lysine must be increased in cereal grains (Lee et al., 2001).

Methionine is among the four essential amino acids that are produced from aspartic acid pathway. Hesse and Hoefgen (2003) reported that amino acids that 
contain sulphur their endogenous level can be increased by variation of biosynthetic path of methionine and cystein in cereals like rice. Cysteine as well as methionine has potential to change physiological processes in vegetation under saline stress (Khan et al., 2014).

Exogenous applications of amino acids regulate physio-chemical developments in crops under varied climatic conditions (Moreira and Moraes, 2017; Ros et al., 2014). For example, exogenous application of amino acids regulate antioxidant defense system in soybean when applied in combination at very low concentration e.g., alanine, glutamate, cysteine and glycine (Teixeira et al., 2017). Alam et al. (2017) reported that amino acids maintain nutrients balance in maize hybrids under salt stress. Some amino acids such as serine, glycine, valine and glutamate play role in improving plant health through therapeutic elements (Moran-Palacio et al., 2014). Proline and glycinebetaine (GB) improve crop production by reducing oxidative stress (Ashraf and Foolad, 2007). Exogenous application of cysteine increase growth in Ocimum basilicum L. under cobalt stress (Azarakhsch et al., 2015), salt stress tolerance in barley (Genisel et al., 2015), and cadmium (Cd) stress in Arabidopsis thaliana (Dominguez-Solis et al., 2004); ); glutamic acid increased salt $(\mathrm{NaCl})$ and cold stress tolerance in Brassica napus L. (Lei et al., 2015, 2016); a mixture of glycine, methionine and tryptophan increased growth of gladiolus plant (Khattab et al., 2016); tryptophan enhanced growth of chickpea under rainfed conditions (Abbas et al., 2013); and proline increased growth of chilli under salinity (Butt et al., 2016).

Methionine contents decreased (upto 40\%) under abiotic stresses (Pavlíková et al., 2014; Zemanová et al., 2014). However, plants treated with methionine have increased resistance to disease. Many efforts have been made to produce food and forage crops with higher methionine contents for both humans and animals respectively. Methionine is an excellent source of essential mineral sulfure that acts as a free radical scavenger in the body (Kumar et al., 2014). So feed with higher level of methionine contents must be applied in the form of forage crops to monogastric animal feed (Bagga et al., 2004). The major goal of recent study is to evaluate the influence of foliar treatments of methionine on the growth as well as physiochemical attributes of maize plants under control and $\mathrm{NaCl}$ stress situations.

\section{MATERIALS AND METHODS}

To assess the influence of foliar use of methionine on two maize varieties Malka and DTC (hybrid) a pot experiment was conducted at the Botanical Garden Government College University, Faisalabad natural climatic environments. Experimental design was completely randomized with three replicates. Seeds of both maize varieties were obtained from Ayub Agricultural Research Institute (AARI) and sown in sand filled plastic pots. There were total 36 pots and six seeds were sown in each pot. Thinning was performed after one week of germination and four plants per pot were kept. Two-week-old maize plants were subjected to two levels of salt stress i.e., 0 and $90 \mathrm{mM}(\mathrm{NaCl})$. Salt treatment was applied in full strength Hoagland's nutrient solution in aliquots of $45 \mathrm{mM}$ for consecutive two days until final volume $90 \mathrm{mM}$ was achieved. Foliar treatment of methionine $\left(0,25\right.$ and $\left.50 \mathrm{mg} \mathrm{L}^{-1}\right)$ was applied to fourweek-old maize plants. Several growth and physiobiochemical parameters were taken of the 11-week-old maize plants.

Growth attributes: Two plants from each pot were collected and measured shoot and root fresh weights and shoot and root lengths. Then oven-dried the leaf samples at $72^{\circ} \mathrm{C}$ for 48 hours and measured the shoot and root dry weights. Total leaf area per plant was calculated by using the formula of Carleton and Foote (1965)

Total leaf area $\left(\mathrm{cm}^{2}\right)=$ leaf length $\times$ leaf width $\times$ correction factor $(0.75)$

Determination of physiobiochemical parameters: Relative water contents (\%): Jones and Turner (1978) method was used for the determination of relative water contents $(\%)$. Fresh leaf $(0.5 \mathrm{~g}) \mathrm{kept}$ in deionized water for 24 hours and turgid weight (Tw) was calculated. Then leaf samples were kept in oven at $80^{\circ} \mathrm{C}$ for 48 hours and measured dry weight (Dw). Following formula was used for relative water contents $(\%)$ determination

$\mathrm{RWC}(\%)=[(\mathrm{Fw}-\mathrm{Tw}) / \mathrm{Fw}-\mathrm{Dw})] \times 100$

Determination of chlorophyll contents: The method of Arnon (1949) was used for the determination of chlorophyll contents. Fresh leaves $(0.5 \mathrm{~g})$ were chopped in $10 \mathrm{ml}$ acetone $(80 \%)$ and kept at $0-4^{\circ} \mathrm{C}$ for overnight. Then absorbance of extract was recorded at optical density of 645 and $663 \mathrm{~nm}$ with a spectrophotometer.

Determination of membrane permeability (\%): Fresh leaves $0.5(\mathrm{~g})$ were cut into small pieces, kept in the test tubes containing $10 \mathrm{ml}$ distilled water, vortexed and measured the electrical conductivity $\left(\mathrm{EC}_{\mathrm{o}}\right)$. Then kept the samples in refrigerator overnight, vortexed and measured the electrical conductivity $\left(E_{1}\right)$. After that autoclaved the samples for one hour, vortexed and measured the electrical conductivity $\left(\mathrm{EC}_{2}\right)$ of dead leaf tissues. Following formulae was used for the estimation of membrane permeability (\%).

$\mathrm{RMP}(\%)=\left(\mathrm{EC}_{1}-\mathrm{EC}_{\mathrm{o}} / \mathrm{EC}_{2}-\mathrm{EC}_{\mathrm{o}}\right) \times 100$

Hydrogen peroxide $\left(\mathrm{H}_{2} \mathrm{O}_{2}\right)$ : Velikova et al. (2000) protocol was used for the determination of $\mathrm{H}_{2} \mathrm{O}_{2}$ contents. Fresh leaf $(0.5 \mathrm{~g})$ finely homogenized in $5 \mathrm{ml}$ of $0.1 \%$ trichloroacetic acid (TCA), centrifuged at $12000 \times$ $g$ for $15 \mathrm{~min}$ and absorbance of reaction mixture $(0.5 \mathrm{ml}$ 
extract $+0.5 \mathrm{ml}$ buffer $+1 \mathrm{ml} \mathrm{KI}$ ) was measured at 390 $\mathrm{nm}$ using a spectrophotometer.

Total free amino acids: Determination of total free amino acids was made according to the procedure reported by Moore and Stain (1957). Citrate buffer (10 ml $\mathrm{pH}$ 5.0) was used for the extraction of fresh leaf material $(0.5 \mathrm{~g})$. The supernatant was centrifuged at $15,000 \times \mathrm{g}$ for $10 \mathrm{~min}$ and added $1 \mathrm{ml}$ each of extract, pyridine and ninhydrin solution in test tubes. Test tubes with samples were kept in water bath at $90^{\circ} \mathrm{C}$ for $30 \mathrm{~min}$ and read the optical density of solution at $570 \mathrm{~nm}$ using a spectrophotometer.

Glycinebetaine determination: Grieve and Grattan (1983) protocol was used for the determination of glycinebetaine. For this fresh leaf $(0.5 \mathrm{~g})$ was extracted in $10 \mathrm{ml}$ of distilled water. To $1 \mathrm{ml}$ of leaf extract added 1 $\mathrm{ml}$ of $2 \mathrm{NH}_{2} \mathrm{SO}_{4}$ and to $0.5 \mathrm{ml}$ of this mixture added 0.2 $\mathrm{ml} \mathrm{K}-\mathrm{I}_{3}$ in an ice bath and cooled for $90 \mathrm{~min}$ at $4^{\circ} \mathrm{C}$. To this mixture added $2.8 \mathrm{ml}$ cold distilled water and $6 \mathrm{ml}$ of 1-2 dichloromethane and read the absorbance at $365 \mathrm{~nm}$ using a spectrophotometer.

Determination of proline: For the determination of lead free proline contents Bates et al. (1973) procedure was used. Fresh leaf $500 \mathrm{mg}$ was homogenized in $10 \mathrm{ml}$ of $3 \%$ sulphosalcylic acid and filtered. To $2 \mathrm{ml}$ of filtrate added $2 \mathrm{ml}$ each of glacial acetic acid and acid ninhydrin and kept the samples in water bath at $80^{\circ} \mathrm{C}$ for 1 hour. After that terminated the reaction by putting the samples in an ice bath, added $4 \mathrm{ml}$ of toluene in each sample and read the absorbance of colored layer at $520 \mathrm{~nm}$ with a spectrophotometer.

Total soluble sugars: Fresh leaf tissue $(0.1 \mathrm{~g})$ was homogenized in phosphate buffer $(5 \mathrm{ml}$ of $0.2 \%)$. To $0.1 \mathrm{ml}$ of supernatant added $3 \mathrm{ml}$ anthron's reagent, vortexed and kept this mixture at $95^{\circ} \mathrm{C}$ for $15 \mathrm{~min}$. After cooling the absorbance of colored extract was taken at $625 \mathrm{~nm}$ using a spectrophotometer.

Determination of total soluble proteins: Bradford (1976) procedure was used for the appraisal of total soluble protein contents. Fresh leaf (500 mg) was finely homogenized in phosphate buffer, centrifuged at $2000 \times g$ for $10 \mathrm{~min}$. To $1 \mathrm{ml}$ of supernatant added $5 \mathrm{ml}$ Coomassie Brilliant blue reagent, vortexed for $20 \mathrm{~s}$ and measured the absorbance of solution at $595 \mathrm{~nm}$ on a spectrophotometer (Hitachi-U-1800, Japan).

Total phenolics: Protocol of Julkenen-Titto (1985) was used for the determination of total phenolic contents. Fresh leaf $(0.5 \mathrm{~g})$ was homogenized in $2 \mathrm{ml}$ of $80 \%$ acetone, homogenized at $10,000 \times g$ for $15 \mathrm{~min}$ and stored at $20^{\circ} \mathrm{C}$. A mixture of $0.1 \mathrm{ml}$ supernatant $+2 \mathrm{ml}$ distilled water $+0.5 \mathrm{ml}$ Folin-Ciocalteau's phenol (FCreagent $)+2.5 \mathrm{ml}$ sodium carbonate $(20 \%)$ prepared and final volume made upto $5 \mathrm{ml}$ with distilled water. Absorbance of mixture was observed at $750 \mathrm{~nm}$ using a spectrophotometer.
Ascorbic acid contents: For the appraisal of ascorbic acid contents method of Mukherjee and Choudhuri (1983) was used. Fresh leaf samples w finely homogenized in liquid nitrogen followed by in a cocktail containing $2 \%$ dinitrophenyl-hydrazine and $6 \%$ trichloroacetic acid prepared in half-strength $\mathrm{H}_{2} \mathrm{SO}_{4}$ and $10 \%$ thiourea dissolved in $70 \%$ ethanol. Then the solution was boiled, cooled at room temperature, centrifuged $(1000 \times g)$ for $10 \mathrm{~min}$ and resultant pellet dissolved in $80 \% \mathrm{H} 2 \mathrm{SO}_{4}$. The absorbance of solution was taken at 530 $\mathrm{nm}$ using a spectrophotometer.

Flavonoids: Method of Zhishen et al. (1999) was used for the determination of flavonoids. Acetone (80\%) was used for the extraction of $0.1 \mathrm{~g}$ fresh leaf samples. Reaction mixture consists of $0.5 \mathrm{ml}$ of supernatant $+2 \mathrm{ml}$ distilled water $+0.6 \mathrm{ml}$ of $5 \% \mathrm{NaNO}_{2}+0.5 \mathrm{ml} 10 \%$ $\mathrm{AlCl}_{3}$ and $2 \mathrm{ml}$ of $1 \mathrm{M} \mathrm{NaOH}$ and reading of solution was made at $510 \mathrm{~nm}$ with a spectrophotometer.

Anthocyanin contents: For the determination of anthocyanin contents fresh leaf sample $(0.1 \mathrm{~g})$ was extracted in phosphate buffer $(5 \mathrm{ml})$, after centrifugation the absorbance of supernatant was performed at $600 \mathrm{~nm}$ with a spectrophotometer

Statistical analysis: A three-way analysis of variance (ANOVA) was performed on the data using statistical package, CoStat program (version v6.303) and means were compared by LSD (least significant difference) (Snedecor and Cochran, 1980).

\section{RESULTS}

Salt stress $(90 \mathrm{mM} \mathrm{NaCl})$ reduced shoot as well as root fresh and dried masses, shoot length, and total leaf area per plant markedly in two maize (Zea mays L.) varieties i.e., DTC (hybrid) and Malika (Table 1; Fig. 1). Two maize cultivars did not display any major alteration but in root fresh weight that was high in var. Malika. Foliar application of methionine (Met) significantly improved dry mass of shoot in addition to root and fresh weight of root in stressed or control states (Table 1; Fig. 1).

Relative water content lessened under stress of $90 \mathrm{mM} \mathrm{NaCl}$ significantly (Table 1; Fig. 1), while all other factors remain unchanged. Photosynthetic pigments such as total chlorophyll contents and chlorophyll $a$ and $b$ molecules diminished under salt $(\mathrm{NaCl})$ stress considerably. Maize varieties exhibited noticeable variations as var. Malika remained greater in chl. $a, b$ and total chlorophyll matters in salinity stressed environments (Table 1; Fig. 2).

Hydrogen peroxide $\left(\mathrm{H}_{2} \mathrm{O}_{2}\right)$ contents increased in var. DTC (hybrid), while decrease in var. Malika under $\mathrm{NaCl}$ stress. Foliar application using different levels of Met enhanced $\mathrm{H}_{2} \mathrm{O}_{2}$ contents noticeably in var. DTC (hybrid), while decrease in var. Malika in both stress 
positions. Salt stress importantly enhanced membrane permeability $(\%)$ in both varieties of maize. Total amino acid reduced under salt stress in both maize varieties significantly, while glycine betaine (GB) and proline contents significantly increase in both maize varieties. However, var. DTC (hybrid) accumulated more GB contents under $\mathrm{NaCl}$ stress conditions (Table 1; Fig. 2).

Total soluble sugars decreased by foliar application of Met in var. DTC (hybrid) under salt stress, while in var. Malika under non stress conditions (Table 1; Fig. 3). Total soluble proteins increased in var. DTC (hybrid) under salt stress conditions, while var. Malika accumulated more proteins in non-stressed situations. Foliar usage of Met enhanced soluble proteins in these two maize varieties under two stress level, whereas reduced in var. DTC (hybrid) under control conditions (Table 1; Fig. 3). DTC (hybrid) and Malika varieties of maize crop indicated important change as var. DTC (hybrid) accumulated high soluble proteins contents under salt stress conditions, while var. Malika excelled under non stress conditions. Both maize varieties also showed significant difference towards Foliar application of Met decreased soluble proteins contents in var. DTC (hybrid), while increased in var. Malika under non stress conditions (Table 1; Fig. 3).

Foliar use of different Met levels improved total phenolic contents in var. Malika significantly, while lessened in var. DTC (hybrid) under saline or control (non-stress) conditions (Table 1; Fig. 3). Ascorbic acid contents enhanced under $\mathrm{NaCl}$ stress condition and through foliar use of Met in DTC (hybrid) and Malika varieties of maize significantly (Table 1; Fig. 3). Anthocyanin contents noticeably enhanced both under salinity and foliar treatment of Met in maize varieties (Table 1; Fig. 3). Both varieties exhibited significant alteration as DTC (hybrid) accumulated high anthocyanin contents than Malika under $\mathrm{NaCl}$ stress application (Table 1; Fig. 3). Flavonoid contents significantly reduced in salt stressed environment in var. Malika. Maize varieties presented significant variance as DTC (hybrid) accumulated high contents of flavonoid under $\mathrm{NaCl}$ stress or control conditions (Table 1; Fig. 3).

Table 1. Analysis of variance of the parameters of growth, relative water content (\%), chlorophyll, hydrogen peroxide, membrane permeability (\%), amino acids, glycinebetaine, proline, total soluble proteins, total soluble sugars, total phenolics, anthocyanin, ascorbic acid and flavonoid contents of maize plants foliarly sprayed with varying levels of methionine (Met) under non saline and saline conditions.

\begin{tabular}{|c|c|c|c|c|c|c|}
\hline Source of variation & df & $\begin{array}{l}\text { Shoot fresh } \\
\text { wt. }\end{array}$ & Shoot dry wt. & $\begin{array}{l}\text { Root fresh } \\
\text { wt. }\end{array}$ & Root dry wt. & Shoot length \\
\hline Varieties (Var) & 1 & $182.25 \mathrm{~ns}$ & $3.497 \mathrm{~ns}$ & $23.36^{* * *}$ & $0.016 \mathrm{~ns}$ & $286.7 \mathrm{~ns}$ \\
\hline Salinity-Stress (SS) & 1 & $4246.6^{* * *}$ & $174.3^{* * *}$ & $26.69^{* * *}$ & $0.397^{* * *}$ & $7140.2^{* * *}$ \\
\hline Methionine (M) & 2 & $137.2 \mathrm{~ns}$ & $30.19^{* *}$ & $5.444^{*}$ & $0.102^{*}$ & $219.4 \mathrm{~ns}$ \\
\hline $\operatorname{Var} \times \mathrm{SS}$ & 1 & $124.6 \mathrm{~ns}$ & $3.297 \mathrm{~ns}$ & $6.25 \mathrm{~ns}$ & $0.001 \mathrm{~ns}$ & $140.8 \mathrm{~ns}$ \\
\hline $\operatorname{Var} \times \mathrm{M}$ & 2 & $115.7 \mathrm{~ns}$ & $4.957 \mathrm{~ns}$ & $1.444 \mathrm{~ns}$ & $0.015 \mathrm{~ns}$ & $47.25 \mathrm{~ns}$ \\
\hline $\mathrm{SS} \times \mathrm{M}$ & 2 & $11.027 \mathrm{~ns}$ & $15.44 \mathrm{~ns}$ & $1.444 \mathrm{~ns}$ & $0.004 \mathrm{~ns}$ & $14.12 \mathrm{~ns}$ \\
\hline $\operatorname{Var} \times \mathrm{SS} \times \mathrm{M}$ & 2 & $53.86 \mathrm{~ns}$ & $1.685 \mathrm{~ns}$ & $0.333 \mathrm{~ns}$ & $0.007 \mathrm{~ns}$ & $30.36 \mathrm{~ns}$ \\
\hline Error & 24 & 92.13 & 4.72 & 1.583 & 0.025 & 79.61 \\
\hline Source of variation & df & Root length & $\begin{array}{l}\text { Total leaf } \\
\text { area plant }^{-1}\end{array}$ & $\begin{array}{l}\text { RWC\% } \\
\text { contents }\end{array}$ & $\begin{array}{l}\text { Chlorophyll } \\
a\end{array}$ & Chlorophyll $b$ \\
\hline Varieties (Var) & 1 & $0.587 \mathrm{~ns}$ & $8041.6 \mathrm{~ns}$ & $117.9 \mathrm{~ns}$ & $0.0379 \mathrm{~ns}$ & $0.018 \mathrm{~ns}$ \\
\hline Salinity-Stress (SS) & 1 & $2.454 \mathrm{~ns}$ & $35661^{* * *}$ & $5849.6^{* * *}$ & $0.0889^{* *}$ & $0.172^{* *}$ \\
\hline Methionine (M) & 2 & $25.25 \mathrm{~ns}$ & $1345 \mathrm{~ns}$ & $239.5 \mathrm{~ns}$ & $0.009 \mathrm{~ns}$ & $0.029 \mathrm{~ns}$ \\
\hline Var $\times \mathrm{SS}$ & 1 & $39.27 \mathrm{~ns}$ & $4220^{* *}$ & $29.95 \mathrm{~ns}$ & $0.2048^{* * *}$ & $0.090^{*}$ \\
\hline $\operatorname{Var} \times \mathrm{M}$ & 2 & $2.138 \mathrm{~ns}$ & $9149 \mathrm{~ns}$ & $65.33 \mathrm{~ns}$ & $0.0028 \mathrm{~ns}$ & $0.0002 \mathrm{~ns}$ \\
\hline $\mathrm{SS} \times \mathrm{M}$ & 2 & $20.79 \mathrm{~ns}$ & $2081 \mathrm{~ns}$ & $12.60 \mathrm{~ns}$ & $0.007 \mathrm{~ns}$ & $0.025 \mathrm{~ns}$ \\
\hline $\operatorname{Var} \times \mathrm{SS} \times \mathrm{M}$ & 2 & $31.18 \mathrm{~ns}$ & $3068 \mathrm{~ns}$ & $0.169 \mathrm{~ns}$ & $0.0123 \mathrm{~ns}$ & $0.039 \mathrm{~ns}$ \\
\hline Error & 24 & 11.64 & 5117 & 80.95 & 0.0104 & 0.017 \\
\hline Source of variation & df & $\begin{array}{l}\text { Total } \\
\text { chlorophyll }\end{array}$ & $\begin{array}{l}\mathrm{H}_{2} \mathrm{O}_{2} \\
\text { contents }\end{array}$ & MP (\%) & Amino acids & $\begin{array}{l}\text { Proline } \\
\text { contents }\end{array}$ \\
\hline Varieties (Var) & 1 & $0.110^{*}$ & $22.34 \mathrm{~ns}$ & $17.26 \mathrm{~ns}$ & $0.302 \mathrm{~ns}$ & $61.76 \mathrm{~ns}$ \\
\hline Salinity-Stress (SS) & 1 & $0.509^{* * *}$ & $3.18 \mathrm{~ns}$ & $752.80^{* * *}$ & $37.22^{*}$ & $4758.7^{* * *}$ \\
\hline Methionine (M) & 2 & $0.072 \mathrm{~ns}$ & $7.593 \mathrm{~ns}$ & $107.48 \mathrm{~ns}$ & $13.79 \mathrm{~ns}$ & $181.0 \mathrm{~ns}$ \\
\hline Var $\times \mathrm{SS}$ & 1 & $0.568^{* * *}$ & $114.1^{* *}$ & $170.65 \mathrm{~ns}$ & $10.35 \mathrm{~ns}$ & $18.34 \mathrm{~ns}$ \\
\hline $\operatorname{Var} \times \mathrm{M}$ & 2 & $0.002 \mathrm{~ns}$ & $30.97^{*}$ & $109.97 \mathrm{~ns}$ & $1.056 \mathrm{~ns}$ & $25.89 \mathrm{~ns}$ \\
\hline $\mathrm{SS} \times \mathrm{M}$ & 2 & $0.016 \mathrm{~ns}$ & $14.33 \mathrm{~ns}$ & $79.51 \mathrm{~ns}$ & $2.631 \mathrm{~ns}$ & $228.52 \mathrm{~ns}$ \\
\hline $\operatorname{Var} \times \mathrm{SS} \times \mathrm{M}$ & 2 & $0.095^{*}$ & $11.05 \mathrm{~ns}$ & $22.21 \mathrm{~ns}$ & $0.499 \mathrm{~ns}$ & $27.113 \mathrm{~ns}$ \\
\hline
\end{tabular}




\begin{tabular}{|c|c|c|c|c|c|c|}
\hline Error & 24 & 0.021 & 8.667 & 43.43 & 5.960 & 210.03 \\
\hline Source of variation & df & GB contents & $\begin{array}{l}\text { Soluble } \\
\text { sugars }\end{array}$ & $\begin{array}{l}\text { Soluble } \\
\text { proteins }\end{array}$ & Ascorbic acid & $\begin{array}{l}\text { Total } \\
\text { phenolics }\end{array}$ \\
\hline Varieties (Var) & 1 & $34.32 \mathrm{~ns}$ & $1847.1^{*}$ & $97.26^{* * *}$ & $1.736 \mathrm{~ns}$ & $4.429 \mathrm{~ns}$ \\
\hline Salinity-Stress (SS) & 1 & $317.5^{* * *}$ & $2.115 \mathrm{~ns}$ & $41.85^{* *}$ & $9.588^{* * *}$ & $5.62 \mathrm{~ns}$ \\
\hline Methionine (M) & 2 & $135.9^{* *}$ & $522.0 \mathrm{~ns}$ & $42.38^{* * *}$ & $3.177^{*}$ & $3.401 \mathrm{~ns}$ \\
\hline Var $\times \mathrm{SS}$ & 1 & $113.9^{*}$ & $608.9 \mathrm{~ns}$ & $141.92^{* * *}$ & $0.019 \mathrm{~ns}$ & $2.018 \mathrm{~ns}$ \\
\hline $\operatorname{Var} \times \mathrm{M}$ & 2 & $51.63 \mathrm{~ns}$ & $852.4^{*}$ & $24.39^{* *}$ & $0.0919 \mathrm{~ns}$ & $11.87^{*}$ \\
\hline $\mathrm{SS} \times \mathrm{M}$ & 2 & $5.335 \mathrm{~ns}$ & $195.10 \mathrm{~ns}$ & $8.646 \mathrm{~ns}$ & $0.213 \mathrm{~ns}$ & $2.31 \mathrm{~ns}$ \\
\hline $\operatorname{Var} \times \mathrm{SS} \times \mathrm{M}$ & 2 & $13.71 \mathrm{~ns}$ & $689.5^{*}$ & $3.335 \mathrm{~ns}$ & $0.402 \mathrm{~ns}$ & $9.13 \mathrm{~ns}$ \\
\hline Error & 24 & 21.48 & 162.0 & 3.036 & 0.584 & 3.034 \\
\hline Source of variation & & & df & Anthocyanin & \multicolumn{2}{|c|}{ Flavonoids } \\
\hline Varieties (Var) & & & 1 & $1.761 \mathrm{~ns}$ & \multicolumn{2}{|c|}{$2.353^{* * *}$} \\
\hline Salinity-Stress (SS) & & & 1 & $6.347^{*}$ & \multicolumn{2}{|c|}{$1.647^{* * *}$} \\
\hline Methionine (M) & & & 2 & $5.814^{*}$ & \multicolumn{2}{|c|}{$0.062 \mathrm{~ns}$} \\
\hline Var $\times \mathrm{SS}$ & & & 1 & $7.098^{*}$ & \multicolumn{2}{|c|}{$1.183^{* * *}$} \\
\hline $\operatorname{Var} \times \mathrm{M}$ & & & 2 & $0.327 \mathrm{~ns}$ & \multicolumn{2}{|c|}{$0.054 \mathrm{~ns}$} \\
\hline $\mathrm{SS} \times \mathrm{M}$ & & & 2 & $0.633 \mathrm{~ns}$ & \multicolumn{2}{|c|}{$0.160 \mathrm{~ns}$} \\
\hline $\operatorname{Var} \times \mathrm{SS} \times \mathrm{M}$ & & & 2 & $0.023 \mathrm{~ns}$ & \multicolumn{2}{|c|}{$0.030 \mathrm{~ns}$} \\
\hline Error & & & 24 & 1.073 & \multicolumn{2}{|c|}{0.064} \\
\hline
\end{tabular}

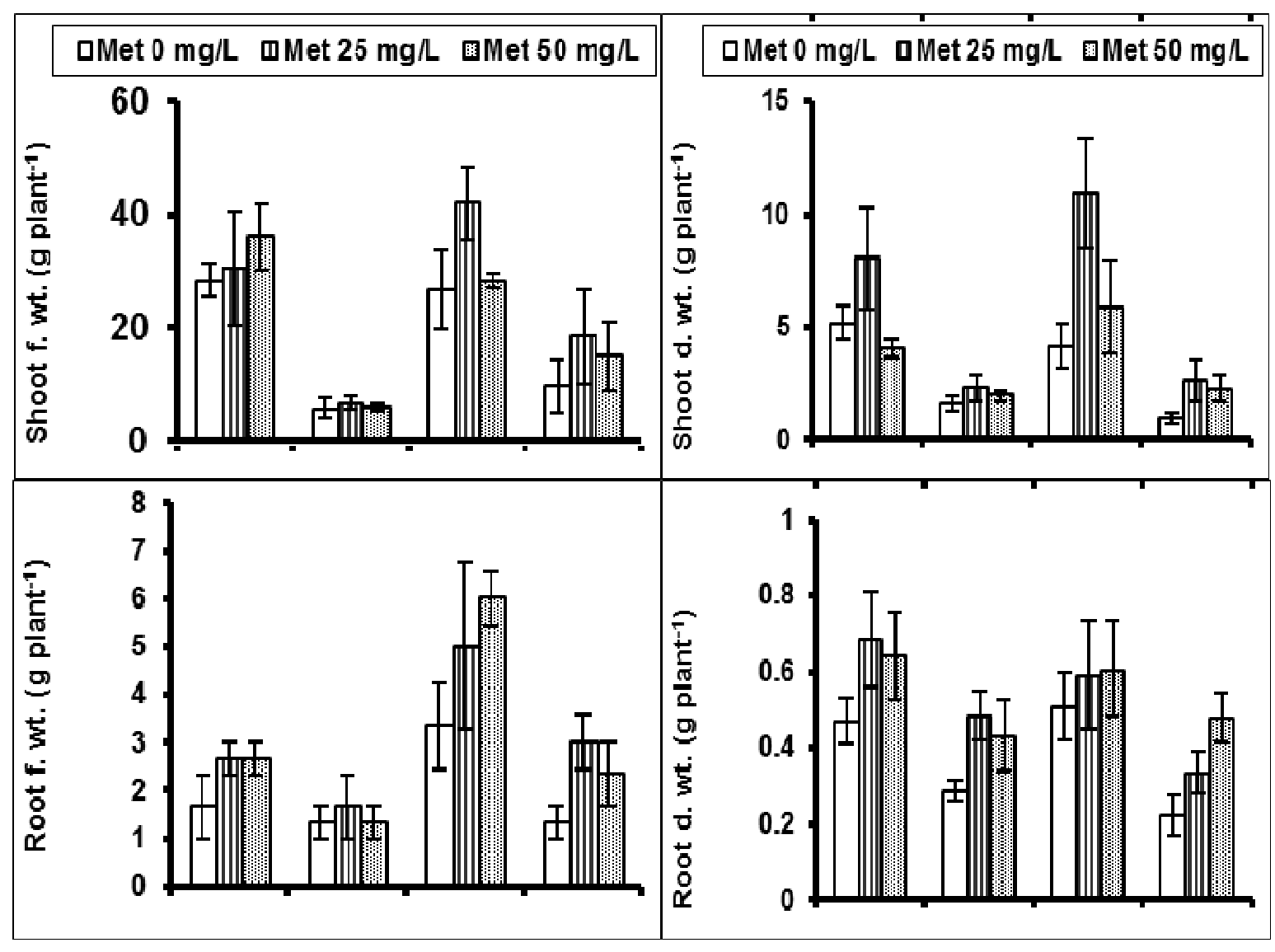




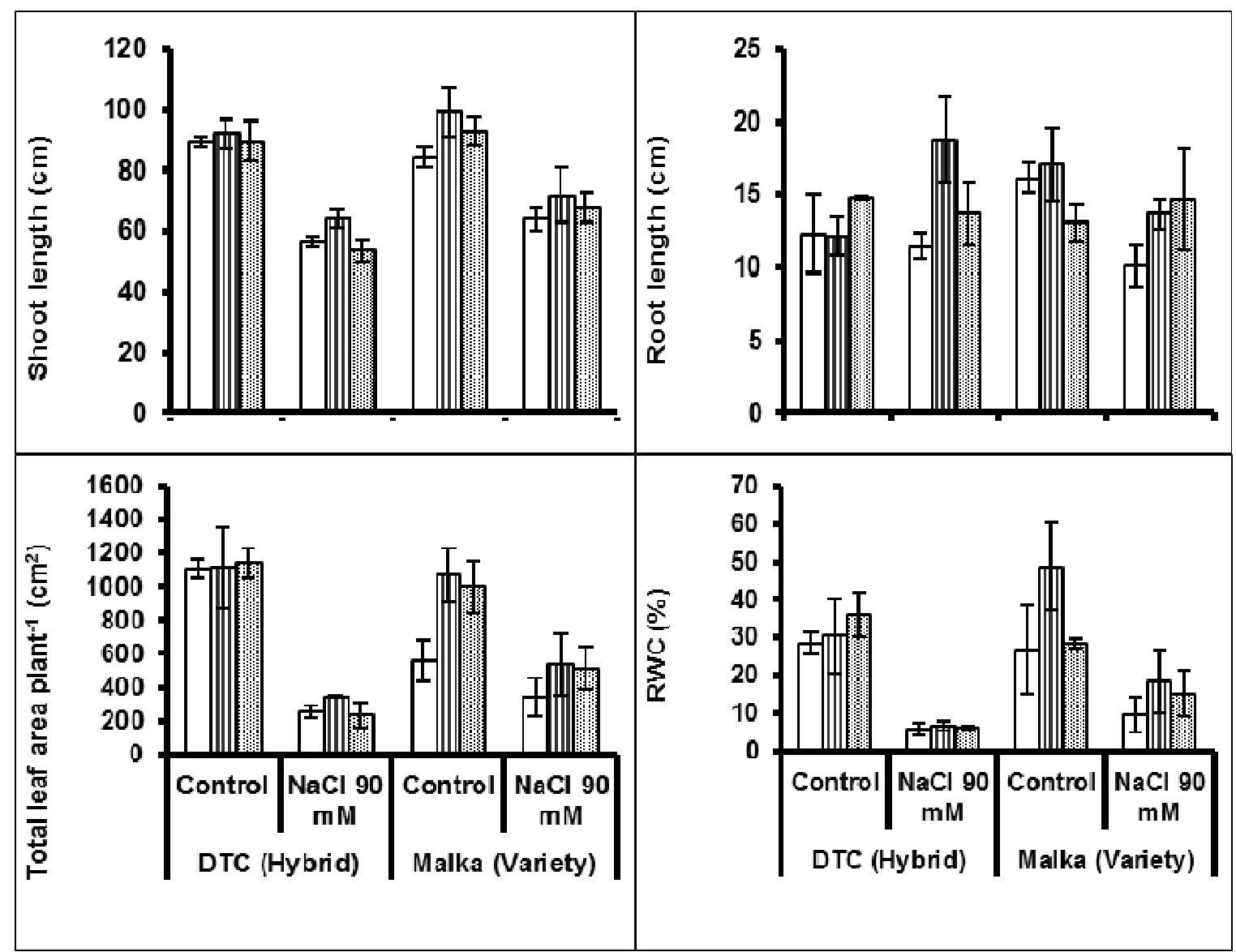

Fig. 1. Growth parameters and relative water contents (\%) of maize (Zea mays L.) plants foliarly-sprayed with methionine under non saline and saline conditions.

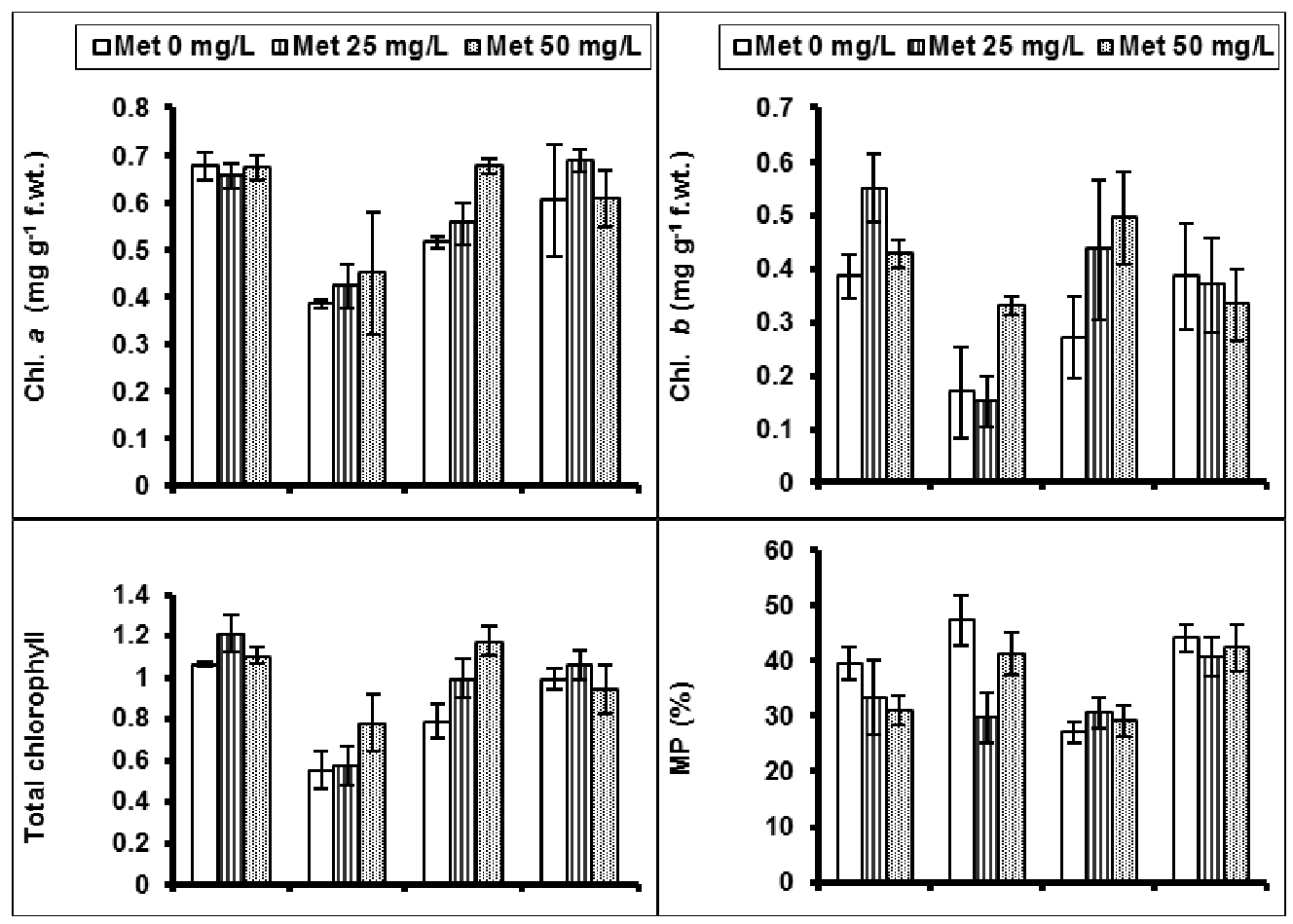




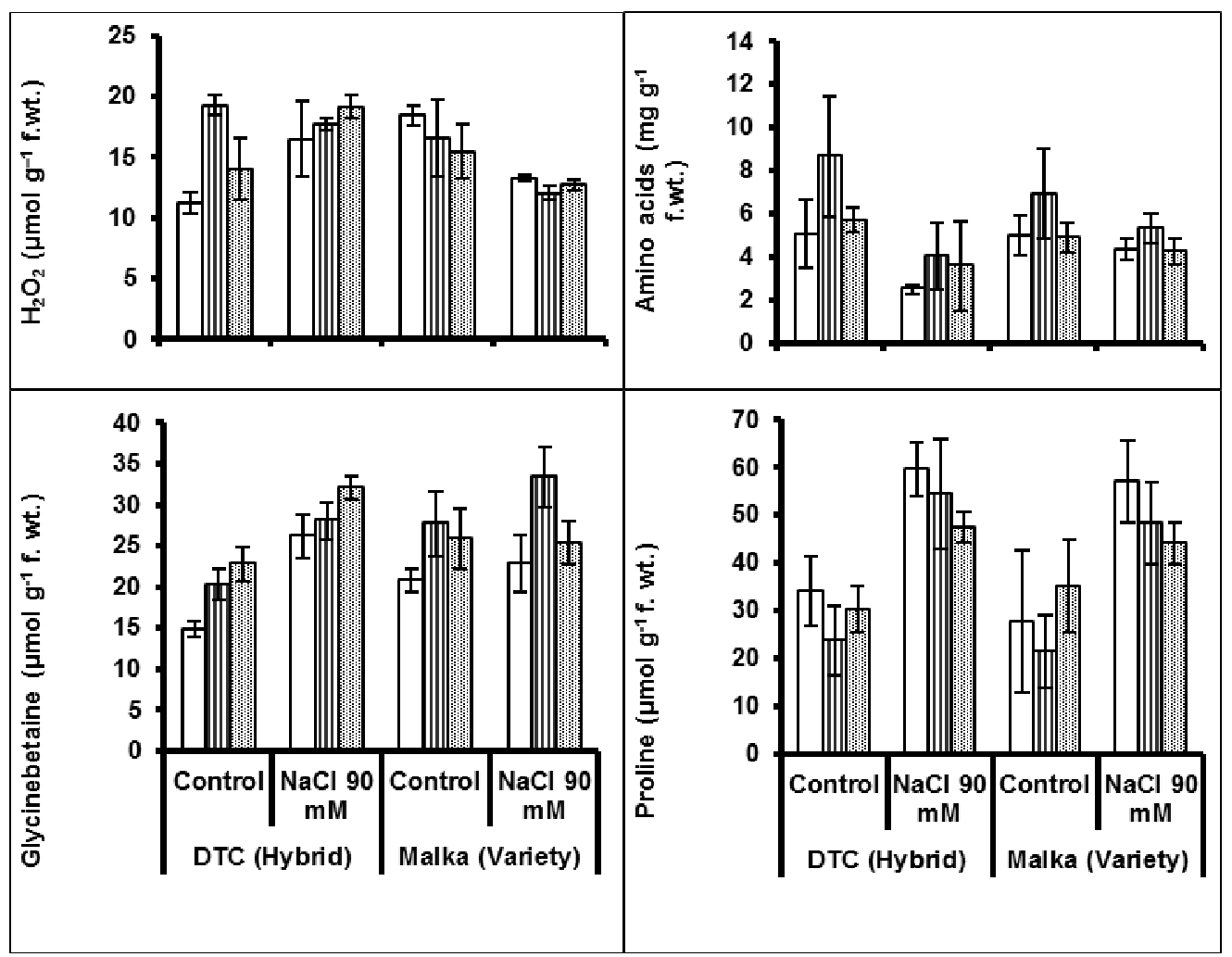

Fig. 2. Chlorophyll, membrane permeability (\%), hydrogen peroxide, amino acids, glycinebetaine and proline contents of maize (Zea mays L.) plants foliarly-sprayed with methionine under non saline and saline conditions.
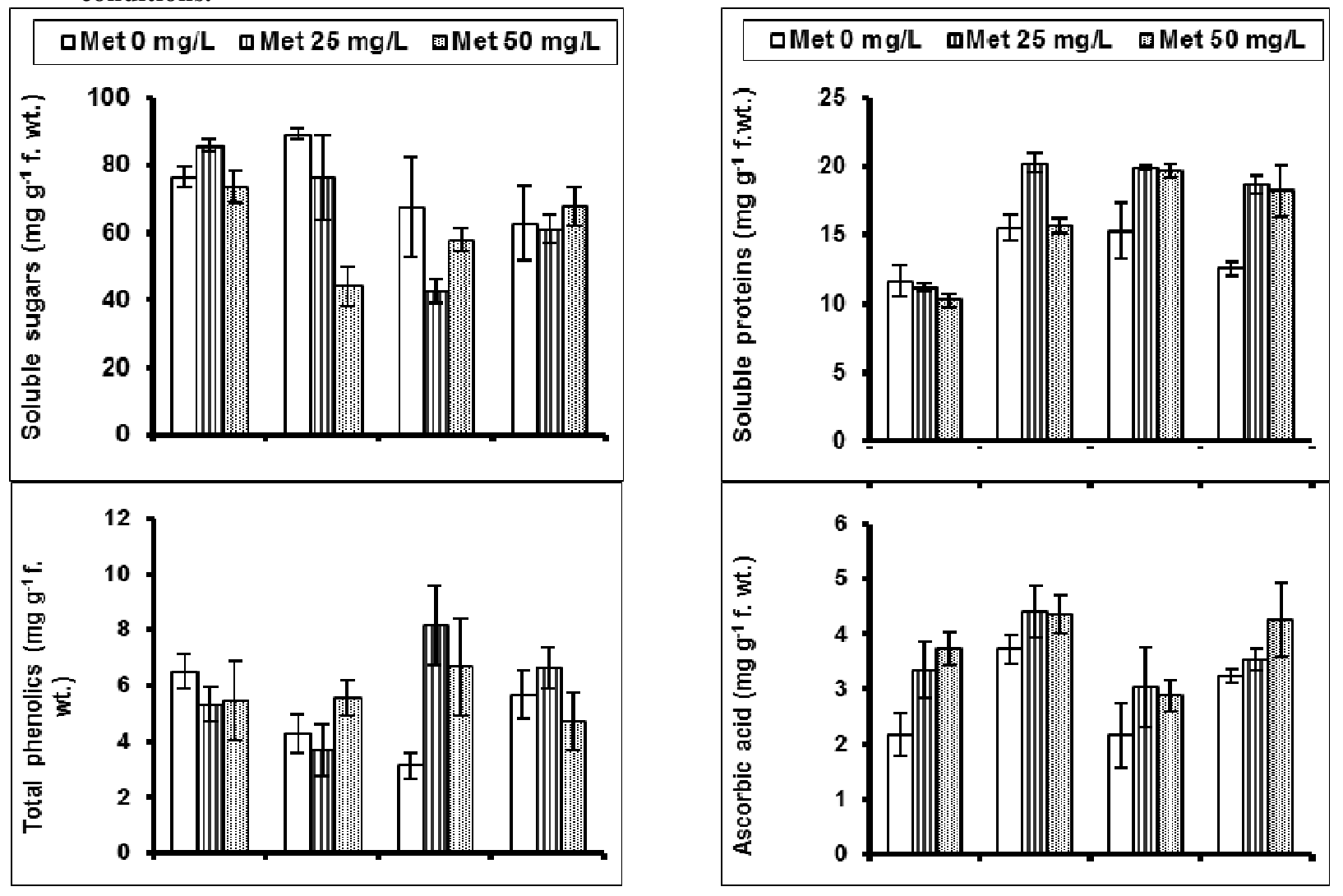

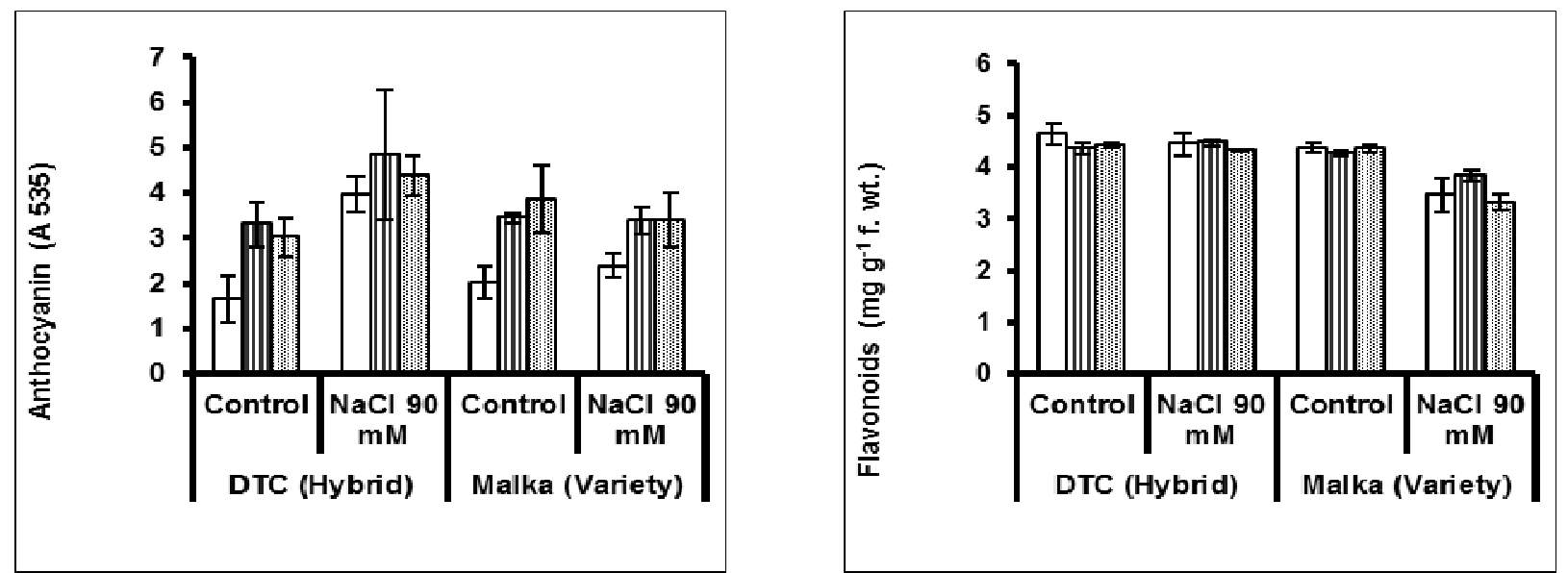

Fig. 3. Contents of total soluble sugars, total soluble proteins, total phenolics, ascorbic acid, flavonoids and anthocyanin of maize (Zea mays L.) plants foliarly-sprayed with methionine under non saline and saline conditions.

\section{DISCUSSION}

Abiotic stresses like salinity, drought and climate change can decrease about $50-70 \%$ crop yield production throughout the world (Mittler, 2006). Salinity stress can afflict $20 \%$ cultivated land and 33\% irrigated land with $10 \%$ annual increase in agricultural area globally (Jamil et al., 2011). Methionine is a sulphurecontaining, non-polar amino acid that has a straight side chain containing S-methyl $\left(-\mathrm{CH}_{3}\right)$ thio-ether at $\gamma$-carbon (Guedes et al., 2011). It enters body through dietary protein and participates in the synthesis of other Scontaining amino acids (Ulrey et al., 2005). It is nutritionally vital amino acid whose low quantity in plants reduces its nutritional protein value for humans and animals (Amir and Hacham, 2008). Methionine oxidized to methionine sulfoxide due to oxidative stress of monooxygenases under abiotic stresses (Zhu et al., 2015; Jacques et al., 2015; Manta and Gladyshev, 2017).

Salt stress decrease growth of shoot by diminishing initiation and expansion of leaf and internodes growth and through increasing leaf abscission ( $\mathrm{Qu}$ et al., 2012). Decline in relative water content (RWC) has been reported in all maize varieties in saline environments (Sairam et al., 2002). El Sayed (2011) reported decline in the photosynthetic pigments in maize (Zea mays L.) crop under $\mathrm{NaCl}$ stress conditions. Hydrogen peroxide $\left(\mathrm{H}_{2} \mathrm{O}_{2}\right)$ level is maintained inside the cell by various types of antioxidant enzymes like peroxidase (POD) and catalase (CAT) (Foyer and Noctor, 2003). Whereas, the concentration of antioxidant enzymes and metabolites can increase or decrease during various environmental conditions ( $\mathrm{Yu}$ and Rengel, 1999). Parvaiz and Satyawati (2008) reported that total free amino acids in plants leaves to be greater in salt resistant as compared to salt sensitive cultivars of sunflower. In this study, ascorbic acid contents increased under $\mathrm{NaCl}$ stress and by usage of methionine as foliar application in both cultivars of maize. Ascorbic acid has been reported to improve growth via increase in fresh and dry weights, photosynthetic pigments i.e., carotenoids, chlorophyll $a$ and $b$ contents, relative water content, proline and activities of antioxidant enzymes, while decreased membrane permeability, malondialdehyde and sodium and chloride ions in red cabbage plants (Hegazi and ElShraiy, 2017).

In present study, contents of glycinebetaine increase in salt stress and foliar treatments of methionine in both varieties of maize. Exogenous treatments of glycinebetaine has been described to enhance salinity tolerance in safflower seedling through improving antioxidant defense system and maintaining nutrients balance (Alasvandyari et al., 2017). Glycinebetaine (GB) containing lines of maize (Zea mays L.) showed less growth inhibition under salt stress conditions. Glycinebetaine (GB) content increased during salinity stress in many plants though it may increase in shoots and may not vary significantly in roots (Wang and Nil, 2000). Kaya et al. (2010) described that proline accumulation increases in maize (Zea mays L.) plants suffering from salinity stress. Ayaz et al. (2000) reported that flavonoids and phenolic compounds are amongst the utmost in effect and widely dispersed secondary metabolites in plants. They show significant eco-physiological roles by involving in tolerance mechanisms of plants against different types of stresses.

In this study, protein contents improved under $\mathrm{NaCl}$ stress and by foliar usage of methionine in two maize varieties. It has been described that plants species accumulate greater contents of protein under salinity stress (Abd El-Samad et al., 2017). Anthocyanins are coloring pigments that belong to flavonoid family of plants and play role against many oxidants under abiotic stresses (Parvaiz et al., 2017). According to 
Kaliamoortiiy and Rao (1994) due to high salt levels anthocyanins accumulate as a stress response. According to Ali and Abbas (2003) Barley (Hordeum vulgare L.) seedlings exposed to sodium chloride $(\mathrm{NaCl})$ suffer from an oxidative stress as seen from its effect on flavonoids, phenolic compounds and oxidant enzymes analyzed in roots and shoots.

Bahmani et al. (2015) reported that the exogenous treatments of sulfur metabolites such as vitamins (thiamine and biotin), amino acids such as methionine and cysteine, thioredoxin system (glutathione, lipoic acid, and glucosinolats) can increase the plants salt stress tolerance. A gene which involved in overexpression of methionine biosynthesis has been revealed to increase tolerance against salinity (Gläser et al., 1993). Genomic study of Arabidopsis thaliana (t365) mutant decreased in S-adenosyl-L-methionine, phosphorethanolamine $\mathrm{N}$-methyltransferase (PEAMT) genetic factor intricate in biosynthesis of glycine betaine (GB) presented hyper-sensitivity to salinity $(\mathrm{NaCl})$ stress (Mou et al., 2002).

Methionine plays various roles in cellular metabolism e.g., as mRNA initiation, translation, protein constituent and as S-adenosylmethionine (SAM) bioregulatory element. It is a precursor of Sadenosylmethionine that is a cofactor and play versatile roles in methyl group transfer and synthesis of polyamines, ethylenes (Fontecave et al., 2004). According to an estimate about $20 \%$ methionine used in protein synthesis and $80 \%$ is converted into $\mathrm{S}$ adenosylmethionine (SAM) formation (Hesse and Hofgen, 2003). S-adenosylmethionine synthetase involved in S-adenosylmethionine synthesis from methionine and ATP is one of the salt stress responsive gene (Ma et al., 2017). SAM is involved in the synthesis of metabolites (polyamines) and of the gaseous plant hormone (ethylene) that play part in regulation of plant retorts to different biotic or abiotic stresses (Gong et al., 2014; Hu et al., 2012; Kollner et al., 2010; Nagel et al., 2008).

In current study, foliar treatment of methionine significantly improved shoot dry mass, fresh root mass, GB, total soluble protein, ascorbic acid and anthocyanin contents of maize varieties (DTC (hybrid) and Malika) in salt stress or controlled conditions. Of the varying methionine levels, $50 \mathrm{mg} \mathrm{L}^{-1}$ proved better in decreasing harmful effect of $\mathrm{NaCl}$ stress in both varieties of maize.

\section{REFERENCES}

Abbas, S. H., M. Sohail, M. Saleem, M. Tariq, I. Aziz, M. Qammar, A. Majeed, and M. Arif (2013). Effects of L-tryptophan on plant weight and pod weight in chickpea under rainfed conditions. Sci. Technol. Dev. 32(4):277-280.
Abd El-Samad, H.M., D. Mostafa, and K.N. Abd ElHakeem (2017). The combined action strategy of two stresses, salinity and $\mathrm{Cu}^{2+}$ on growth, metabolites and protein pattern of wheat plant. Amer. J. Plant Sci. 8:625-643.

Alam, R., D.K. Das, M.R. Islam, Y. Murata, and M.A. Hoque (2017). Exogenous proline enhances nutrient uptake and confers tolerance to salt stress in maize (Zea mays L.). Progress. Agric. 27(4):409-417.

Alasvandyari, F., B. Mahdavi, and S.M. Hosseini (2017). Glycinebetaine affects the antioxidant system and ion accumulation and reduces salinity induced damage in safflower seedlings. Arch. Biol. Sci. 69(1):139-47.

Ali, R.M, and H.M. Abbas (2003). Response of salt stressed barley seedlings to phenylurea. Plant Soil Environ. 49(4):158-162.

Amir R., and Y. Hacham (2008). Methionine metabolism in plants, in Sulfur: A Missing Link Between Soils, Crops, and Nutrition, ed. Jez J., editor. (Madison: American Society of Agronomy, Crop Science Society of America, Soil Science Society of America 251-279.

Arnon, D.T. (1949). Copper enzyme in isolated chloroplasts polyphenoloxidase in Beta vulgaris. Plant Physiol. 24:1-15.

Ashraf, M., and M.R. Foolad (2007). Role of glycine betaine and proline in improving plant abiotic stress resistance. Environ. Exp. Bot. 59:206-216.

Awad, E.M., A.M. Abd El-Hameed and Z.S. Shall (2007). Effect of glycine, lysine and nitrogen fertilizer rates on growth, yield and chemical composition of potato. J. Agric. Sci. Mansoura Univ. 32(10):8541-8551.

Ayaz, F.A., A. Kadioglu, and R. Turgut (2000). Water stress effects on content of low molecular weight carbohydrates and phenolic acids in Ctenanthe setosa (Rosc.) Eichler. Can. J. Plant Sci. 80:373-378.

Azarakhsh, M.R., Z. Asrar, and H. Mansouri (2015). Effect of seed and vegetative stage cysteine treatments on oxidative stress response molecules and enzymes in Ocimum basilicum L. under cobalt stress. J. Soil Sci. Plant Nutri. 15(3):651-662.

Bagga, S., A. Armendaris, N. Klypina, I. Ray, S. Ghoshroy, M. Endress, D. Sutton, J.D. Kemp, and C. Sengupta-Gopalan (2004). Genetic engineering ruminal stable high methionine protein in the foliage of alfalfa. Plant Sci. 166:273-283.

Bahmani, K., S.A.S. Noori, A. I. Darbandi, and A. Akbari (2015). Molecular mechanisms of plant salinity tolerance: a review. Aust. J. Crop Sci. 9(4):321. 
Bates, I.S., R. P. Waldren, and I.D. Teare (1973). Rapid determination of free proline for water stress studies. Plant Soil 39:205-207.

Bradford, M.M. (1976). A rapid and sensitive method for the quantitation of microgram quantities of protein utilizing the principle of protein-dye binding. Annal. Biochem. 72:248-254.

Butt, M., C.M. Ayyub, M. Amjad, and R. Ahmad (2016). Proline application enhances growth of chilli by improving physiological and biochemical attributes under salt stress. Pakistan J. Agric. Sci. 53:43-49.

Carleton and Foote (1965). A comparison of methods for estimating total leaf area of barley plants. Crop Sci. 5(6):602-603.

Dominguez-Solis, J.R., M.C. Lopez-Martin, F.J. Ager, M.D. Ynsa, L.C. Romero, and C. Gotor (2004). Increased cysteine availability is essential for cadmium tolerance and accumulation in Arabidopsis thaliana. Plant Biotechnol. J. 2(6):469-476.

El Sayed, H.E.S.A. (2011). Influence of salinity stress on growth parameters, photosynthetic activity and cytological studies of Zea mays L. plant using hydrogel polymer. Agr. Biol. J. N. Am 2:907920.

El-Said, M.A.A., and A.Y. Mahdy (2016). Response of two wheat cultivars to foliar application with amino acids under low levels of nitrogen fertilization. J. Middle East. 5(4):462-472.

Fontecave, M., M. Atta, and E. Mulliez (2004). SAdenosyl methionine: nothing goes to waste. Trends Biochem. Sci. 29:243-9.

Foyer, C.H., and G. Noctor (2003). Redox sensing and signaling associated with reactive oxygen in chloroplasts, peroxisomes and mitochondria. Physiol. Plant. 119:355-364.

Genisel, M., S. Erdal, and M. Kiilkava (2015). The mitigating effect of cysteine on growth inhibition in salt stressed barley seeds are related to its own reducing capacity rather than its effects on antioxidant system. Plant Growth Regul. 75:187-197.

Gläser, H.U., D. Thomas, R. Gaxiola, F. Montrichard, Y. Surdin-Kerjan, and R. Serrano (1993). Salt tolerance and methionine biosynthesis in Saccharomyces cerevisiae involve a putative phosphatase gene. EMBO J. 12(8):3105.

Gong, B., X. Li, K.M. Vanden Langenberg, D. Wen, S. Sun, M. Wei, Y. Li, F. Yang, Q. Shi, and X. Wang (2014). Overexpression of S-adenosyl-Lmethionine synthetase increased tomato tolerance to alkali stress through polyamine metabolism. Plant Biotechnol. J. 12:694-708.
Grieve, C.M., and S.R. Grattan (1983). Rapid assay for the determination of water soluble quaternary ammonium compounds. Plant Soil 70:303-307.

Guedes, R.L., F. Prosdocimi, G.R. Fernandes, L.K. Moura, H.A. Ribeiro, and J.M. Ortega. (2011).Amino acids biosynthesis and nitrogen assimilation pathways: A great genomic deletion during eukaryotes evolution. BMC Genom. 12(4): S2.

Hegazi, A.M., and A.M. El-Shraiy (2017). Stimulation of photosynthetic pigments, anthocyanin, antioxidant enzymes in salt stressed red cabbage plants by ascorbic acid and potassium silicate. Middle East J. Agric. Res. 6(2):553-568.

Hesse, H., and R. Hoefgen (2003). Molecular aspects of methionine biosynthesis. Trends Plant Sci. $8(6): 259-262$.

Hesse, H., O. Kreft, S. Maimann, M. Zeh, and R. Hoefgen (2004). Current understanding of the regulation of methionine biosynthesis in plants. J. Exp. Bot. 55:1799-1808.

Hu, X., Y. Zhang, Y. Shi, Z. Zhang, Z. Zou, H. Zhang, and J. Zhao (2012). Effect of exogenous spermidine on polyamine content and metabolism in tomato exposed to salinityalkalinity mixed stress. Plant Physiol. Biochem. 57:200-209.

Jacques, S., B. Ghesquiere, P. De Bock, H. Demol, K. Wahnig, P. Willems, J. Messens, F.V. Breusegem, and K. Gevaert (2015). Protein methionine sulfoxide dynamics in Arabidopsis thaliana under oxidative stress. Mol. Cell. Proteom. 14:1217-1229.

Jamil, A., S. Riaz, M. Ashraf, and M.R. Foolad (2011). Gene expression profiling of plants under salt stress. Crit. Rev. Plant Sci. 30(5):435-458.

Jones, M.M., and N.C. Turner (1978). Osmotic adjustment in leaves of sorghum in response to water deficits. Plant Physiol. 61:122-126.

Julkenen-Titto, R. (1985). Phenolic constituents in the leaves of northern willows: methods for the analysis of certain phenolics. J. Agric. Food Chem. 33:213-217.

Kaliamoortiiy, S., and A.S. Rao (1994). Effect of salinity on anthocyanin accumulation in the root of maize. Science 248:1637-1638.

Kaya, C., A.L. Tuna, and A.M. Okant (2010). Effect of foliar applied kinetin and indole acetic acid on maize plants grown under saline conditions. Turk. J. Agric. For. 34:529-538.

Khan, N.A., M. Iqbal, R. Khan, M. Asgher, M. Fatm, A. Masood, and S. Syeed (2014). Salinity tolerance in plants: revisiting the role of sulfur metabolites. J. Plant Biochem. Physiol. 2:1.

Khattab, M., A. Shehata, E. A. El-Saadate, and K. AlHasni (2016). Effect of glycine, methionine and 
tryptophan on the vegetative growth, flowering and corms production of Gladiolus plant. Alexan. Sci. Exchange J. 37(4):647-659.

Köllner, T.G., C. Lenk, N. Zhao, I. Seidl-Adams, J. Gershenzon, F. Chen, and J. Degenhardt (2010). Herbivore-induced SABATH methyltransferases of maize that methylate anthranilic acid using Sadenosyl-L-methionine. Plant Physiol. 153:1795-1807.

Kumar, G., H. Chaurasia, D.V. Rai, and Jayanand (2014). Nutritional quality enhancement of plants by improving its methionine content. Int. J. Res. Develop. Pharm. Life Sci. 3(2):859-865.

Langridge, P., and D. Fleury (2011). Making the most of 'omics' for crop breeding. Trends Biotechnol. 29:33-40.

Lee, S.J., H.U. Kim, Y.H. Lee, S.C. Suh, Y.P. Lim, H.Y. Lee, and H.I. Kim (2001). Constitutive and seed-specific expression of a maize lysinefeedback-insensitive dihydrodipicolinate synthase gene leads to increased free lysine levels in seeds. Mol. Breed. 8:75-84.

Lei, P., H. Xu, Y. Ding, B. Tang, Y. Zhang, H. Li, and H. $\mathrm{Xu}$. (2015). Effect of poly ( $\gamma$-glutamic acid) on the physiological responses and calcium signaling of rape seedlings (Brassica napus L.) under cold stress. J. Agric. Food Chem. 63(48):10399-10406.

Lei, P., Z. Xu, J. Liang, X. Luo, Y. Zhang, X. Feng, and $\mathrm{Z}$. $\mathrm{Xu}$ (2016). Poly ( $\gamma$-glutamic acid) enhanced tolerance to salt stress by promoting proline accumulation in Brassica napus L. Plant Growth Regul. 78:233.

Ma, C., Y. Wang, D. Gu, J. Nan, S. Chen, and H. Li. (2017). Overexpression of S-adenosyl-Lmethionine synthetase 2 from sugar beet M14 increased Arabidopsis tolerance to salt and oxidative stress. Int. J. Mol. Sci. 18:847.

Manta, B., and V.N. Gladyshev (2017). Regulated methionine oxidation by monooxygenases. Free Radical Biol. Med. 109:141-155.

Mittler, R. (2006). Abiotic stress, the field environment and stress combination. Trends Plant Sci. 11:1519.

Moore, S., and W.H. Stein (1957). A modified ninhydrin Reagent for the photometric determination of amino acids and related compounds. J. Biol. Chem. 211:907-913.

Moran-Palacio E., L. Zamora-Álvarez, N. StephensCamacho, G. YáñezFarías, A. Virgen-Ortiz, O. Martínez-Cruz, and J. Rosas-Rodríguez (2014). Antioxidant capacity, radical scavenging kinetics and phenolic profile of methanol extracts of wild plants of southern Sonora, Mexico. Trop. J. Pharm. Res. 13(9):1487-1493.
Moreira, A., and L.A.C. Moraes (2017). Yield, nutritional status and soil fertility cultivated with common bean in response to amino-acids foliar application. J. Plant Nutr. 40(3):344-351.

Mou, Z., X. Wang, Z. Fu, Y. Dai, C. Han, J. Ouyang, F. Bao, Y. Hu, and J. Li (2002). Plant Cell 14:2031-2043.

Mukherjee, S.P., and M.A. Choudhuri (1983). Implications of water stress-induced changes in the levels of endogenous ascorbic acid and hydrogen peroxide in Vigna seedlings. Physiol. Plant. 58:166-170.

Muntz, K., V. Christov, G. Saalbach, I. Saalbach, D. Waddel, T. Pickardt, O. Schieder and T. Wustenhagen (1998). Genetic engineering for high methionine grain legumes. Nahrung 42:125-127.

Nagel, J. L.K. Culley, Y. Lu, E. Liu, P.D. Matthews, J.F. Stevens, and J.E. Page (2008). EST analysis of hop glandular trichomes identifies an Omethyltransferase that catalyzes the biosynthesis of xanthohumol. Plant Cell 20:186-200.

Nazar, R., N. Iqbal, S. Syeed, and N.A. Khan (2011). Salicylic acid alleviates decreases in photosynthesis under salt stress by enhancing nitrogen and sulfur assimilation and antioxidant metabolism differentially in two mungbean cultivars. J. Plant Physiol. 168(8):807-815.

Parvaiz, A., and S. Satyavati (2008). Salt stress and phyto-biochemical responses of plants-a review. Plant Soil Environ. 54:89-99.

Parvaiz, T., J. Songtao, F. Faghihi, M.S. Haider, and J. Fang (2017). Naturally occurring anthocyanin, structure, functions and biosynthetic pathway in fruit plants. J. Plant Biochem. Physiol. 5:187. doi:10.4172/2329-9029.1000187

Pavlíková, D., M. Pavlík, D. Procházková, V. Zemanová, F. Hnilička, and N. Wilhelmová (2014). Nitrogen metabolism and gas exchange parameters associated with zinc stress in tobacco expressing an ipt gene for cytokinin synthesis. J. Plant Physiol. 171:559-564.

Pfefferle,W., B. Mockel, B. Bathe, and A. Marx (2003). Biotechnological manufacture of lysine. In Advances in Biochemical Engineering/ Biotechnology, Vol 79 Microbial Production of L-Amino Acids, Sheper, T., ed. (Berlin: Springer-Verlag) pp. 59-112.

Qu, C., C. Liu, X. Gong, C. Li, M. Hong, L. Wang and F. Hong (2012). Impairment of maize seedling photosynthesis caused by a combination of potassium deficiency and salt stress. Environ. Exp. Bot. 75:134-141.

Ros, R., J. Muñoz-Bertomeu, and S. Krueger (2014). Serine in plants: biosynthesis, metabolism, and functions. Trends Plant Sci. 19(9):564-569. 
Sadak M.S.H, M.T. Abdelhamid, and U. Schmidhalter (2015). Effect of foliar application of aminoacids on plant yield and physiological parameters in bean plants irrigated with seawater. Acta Biol. Colomb. 20(1):141-152

Sairam, R.K., K.V. Rao, and G.C. Srivastava (2002). Differential response of wheat genotypes to long term salinity stress in relation to oxidative stress, antioxidant activity and osmolyte concentration. Plant Sci. 163:1037-1046.

Snedecor, G.W., and G.W. Cochran (1980). Statistical Methods. $7^{\text {th }}$ edition. The Lowa State University Press. Ames, Lowa.

Stiller I., G. Dancs, H. Hesse, R. Hoefgen, and Z. Banfalvi (2007). Improving the nutritive value of tubers: elevation of cysteine and glutathione contents in the potato cultivar White Lady by marker-free transformation. J. Biotechnol. 128:335-343.

Teixeira W.F., E.B. Fagan, L.H. Soares, R.C. Umburanas, K. Reichardt, and D.D. Neto (2017). Foliar and seed application of amino acids affects the antioxidant metabolism of the soybean crop. Front Plant Sci. 8:327. doi: 10.3389/fpls.2017.00327.

Ulrey, C.L., L. Liu, L.G. Andrews, and T.O. Tollefsbol (2005). The impact of metabolism on DNA methylation. Hum. Mol. Genet. 14 Special Issue No 1:R139-147.

Velikova, V., I. Yordanov, and A. Edreva (2000). Oxidative stress and some antioxidant systems in acid rain-treated bean plants: protective roles of exogenous polyamines. Plant Sci. 151:59-66.

Wang, H., N. Bi, Y. Saito, Y. Wang, X. Sun, and J. Zhang (2010). Recent changes in sediment delivery by the Huanghe (Yellow River) to the sea: Causes and environmental implications in its estuary. J. Hydrol. 391:302-313.
Wang, Y., and N. Nil (2000). Changes in chlorophyll, ribulose biphosphate carboxylase-oxygenase, glycine betaine content, photosynthesis and transpiration in Amaranthus tricolor leaves during salt stress. J. Hortic. Sci. Biotechnol. 75:623-627.

Xiaochuang, C., Z. Chu, Z. Lianfeng, Z. Junhua, S. Hussain, W. Lianghuan, and J. Qianyu (2017). Glycine increases cold tolerance in rice via the regulation of $\mathrm{N}$ uptake, physiological characteristics, and photosynthesis. Plant Physiol. Biochem. 112:251-260.

Xu, S., J. Harrison, W. Chalupa, C. Sniffen, W. Julien, H. Sato, T. Fujieda, K. Watanabe, T. Ueda, and H. Suzuki (1998). The effect of ruminal bypass lysine and methionine on milk yield and composition of lactating cows. Dairy Sci. 81:1062-1077.

Yu, Z., and Q. Rengel (1999). Drought and salinity differentially influence activities of superoxide dismutase in narrow leafed lupines. Plant Sci. 141:1-11.

Zemanová, V., M. Pavlík, D. Pavlíková, and P. Tlustoš (2014). The significance of methionine, histidine and tryptophanin plant responses and adaptation to cadmium stress. Plant Soil Environ. 60(9):426-432.

Zhishen, J., T. Mengcheng, and W. Jianming (1999). The determination of flavonoid contents in mulberry and their scavenging effects on superoxide radicals. Food Chem. 64:555-559.

Zhu, J., P. Ding, Q. Li, Y.K. Gao, F. Chen, and G. Xia (2015). Molecular characterization and expression profile of methionine sulfoxide reductase gene family in maize (Zea mays) under abiotic stresses. Gene 562:159-168. 